\title{
Svensk forsvar på kurs mod kollaps
}

Johan Tunberger

Sverige har haft fred i snart 200 år, og krigsperspektivet er næsten fortrængt i den militære planlægning. Med en forværret økonomi har det afgørende været, hvordan man erstatter en stor krigsorganisation fra Den Kolde Krig med nyt og moderne materiel?

Nytårsaften 2012 publicerede den store morgenavis Svenska Dagbladet et interview med den svenske forsvarschef Sverker Göranson. Han erklærede, at det svenske forsvar kunne modstå et - underforstået russisk - geografisk og styrkemessigt meget begrenset angreb i en uge. Derefter måtte Sverige have hjælp af NATOlande.

Udtalelsen vakte sensation. Det fåtal af forsvarsinteresserede - heriblandt undertegnede - som i avisartikler og på blogs i mange år har peget på manglerne i det svenske forsvar fik altså ret af landets højeste militære chef.

'En-ugesforsvaret' blev flittigt omtalt $i$ alle medier. Regeringen tav $i$ en uge. Til sidst erklærede forsvars- minister Karin Enström, at forsvarschefens beskrivelse af landets forsvarsevne var rigtig, men at selv denne evne faktisk var 'rimelig'.

For første gang i meget lang tid kom der en debat om det svenske forsvars militære evner. Selv folk, som formodentlig aldrig har skænket forsvaret en tanke, var rystede; for vi betaler jo trods alt 40 milliarder svenske kroner om året. Tidligere var der forekommet sporadiske diskussioner om nedlæggelse af kaserner og flyvestationer, beslutninger om anskaffelse af nye kampfly osv.; men forsvarets operative evne havde aldrig været et tema. Her og der var spørgsmålet om medlemskab af NATO blevet rejst; men berøringsangsten i forhold til vestalli- 
ancen sidder dybt i det svenske samfund. Dette har dog ikke været til hinder for, at det svenske forsvar har et omfattende og velkendt samarbejde med NATO, mere omfattende end mange medlemslandes.

Det bidrog også til dramatikken omkring 'en-ugesforsvaret', at Sverker Göranson pludselig blev syg i halvanden måned. Det medførte en intensiv rygtedannelse om, at regeringen var i færd med at afsætte ham.

Underhånden kom det også frem, at hans udtalelse om 'en-ugesforsvaret' ikke var møntet på situationen i dag, men hvordan den kunne tænkes at se ud i 2020. På det tidspunkt skal nemlig ifølge den militære planlægning forsvarets igangværende omstrukturering, som bl.a. indebærer afskaffelse af værnepligten, være klar. Denne organisation blev vedtaget af Riksdagen i 2009 og kaldes Indsatsorganisation 2014 (IO 14).

\section{'En-ugesforsvaret'}

Helt frem til, at forsvarschefen lod sin bombe falde, havde især Moderaternes (de konservatives) forsvarspolitikere udbasuneret, at IO 14 ville have et højt indsatsberedskab 'her og nu', og at Sveriges forsvarsevne dermed ville blive meget væsentligt styrket.

Forsvarsministeren fortsætter flittigt med at bidrage til den kognitive dissonans ved på en gang at hævde, at hele landet skal forsvares, og at den nye organisation skal indfases i den takt, økonomien tillader - hvilket de fleste kyndige fortolker som aldrig.

Den utopiske organisation IO 14 er meget lille. Nogle eksempler: Hæren er tænkt at skulle have fire panserbataljoner, fire panserinfanteribataljoner, 24 haubitsere og 45 kampvogne. Flyvevåbnet antages at skulle have 60-80 jagerbombefly (JAS) og søværnet syv kystkorvetter og fire ubåde. Den samlede personelstyrke i alle værn er planlagt til ca. 9.000 officerer og underofficerer, 16.000 soldater (hvoraf 9.000 'deltids tjenestegørende', altså reservister) og $22.000 \mathrm{i}$ hjemmeværnet.

Skønt politikerne længe stædigt talte om IO 14, som om den faktisk eksisterede, fremgik det meget snart, at IO 14 tidligst kunne være gennemført i 2019. I marts 2013 fremkom en oplysning - med vilje godt gemt i et militært dokument om, at end ikke den lille organisation IO 14 kunne være fuldt bemandet før 2023! Men for at nå dette mål med ti års forsinkelse hævdede forsvarets ledelse, at der ville være behov for yderligere 4,5 milliarder kroner om året i perioden 2015-25.

Bevillingerne skulle altså øges med ti procent for at etablere 'enugesforsvaret"' med ti års forsinkelse!

Det svenske forsvar er i dag en Potemkinkulisse, og det vil det blive ved med at være, blot endnu mere nedslidt, hvis der ikke skydes penge til i mindst den størrelsesorden, som 
man kræver fra militært hold. Meget lidt tyder på, at der findes politiske forudsætninger for, at vil ske.

Betegnelsen Potemkinkulisse kan forekomme brutal, men kan begrundes. Ganske vist er der mange gode våbensystemer i det svenske forsvar, fx kampflyet JAS 39 Gripen, moderne kampvogne og effektive ubåde. Men det er et gennemgående træk, at alle værn mangler vitale komponenter for at få fuld systemeffekt. Og selv om det ved et mirakel skulle lykkes at få etableret IO 14 'en-ugesforsvaret' - i fremtiden, ville mange af manglerne stadig gøre sig gældende. Det gælder bl.a. ledelsessystemer, artilleri, luftforsvarsraketter og ikke mindst logistik. Hertil kommer, at personelstyrken selv i en fuldt gennemført IO 14 er meget lille. Anekdotisk kan det nævnes, at den vel gennemførte Libyenindsats med fem JAS-fly tvang flyvevåbnet til at skrabe bunden af sine ressourcer; så tyndt er det højest prioriterede værn. Der er betydelige mangler med hensyn til piloternes flyvetid, flyvestationer og deres beskyttelse med luftværnsraketter, kampledelse, jordpersonel og våben.

\section{Tikkende bomber}

Fire bomber tikker i det svenske forsvar. Hvis ikke forsvaret får mindst de yderligere bevillinger, det har bedt om, vil de detonere samtidig $\mathrm{i}$ slutningen af dette årti. De fire bomber udgør tilsammen a perfect storm, som lægger op til et systemsammenbrud.

Værnepligten blev afskaffet hovedkulds i 2009 uden grundig analyse, uden at lovgivningen var på plads og med beregninger, som groft undervurderede omkostningerne. Det har vist sig svært at rekruttere især deltids tjenestegørende soldater (reservister), hvilket næppe overrasker en dansk læser. Selv de fuldtids tjenestegørende forlader tjenesten tidligere end beregnet. Antallet af kvalificerede, som $\emptyset$ nsker at blive officer, er faldet dramatisk. Der skal flere penge til.

For at imødekomme det politiske krav om 'en økonomi i balance', dvs. undgå de tidligere almindelige underskud, gennemfører forsvaret ikke større øvelser fx på brigade- eller bataljonsniveau. I bedste fald har man øvelser på kompagniniveau, men almindeligvis på delingsniveau. Dette betyder, at forsvaret som et 'system af systemer' er i hastig opløsning. For øvrigt er det for tiden kun en eneste fuldt bemandet bataljon.

For at aktiviteten i form af øvelser, uddannelse med mere ikke skal mindskes endnu mere har regeringen for at holde ' $\varnothing$ konomien i balance' bestemt, at forsvaret skal skyde en stadigt voksende 'snebold' af velmotiverede materielordrer foran sig. Det drejer sig om alt fra standardlastbiler til ledelsessystemer. Det udgør et stadigt voksende bjerg af udgifter, som vurderes til mere end 30 milliarder i tiårsperioden. 
Kort sagt suger det svenske forsvar på labben og tvinges til at æde af sin kapital (Dette udvikles i bogen För Sveriges säkerhet, som for nylig er udgivet af Kungl. Krigsvetenskapsakademien)

Det er sandsynligt, at Sverige vil anskaffe 60 JAS E. Dette fly præsenteres politisk som en 'opgradering' af de JAS C/D, som endnu ikke er færdigproducerede. Men i virkeligheden er der tale om et fly, som for tre fjerdedeles vedkommende er nyt. Det er bl.a. større, har ny motor og ny elektronisk styret radar og anden flyelektronik. Regeringen har anslået de totale omkostninger til 90 milliarder kroner fordelt over 30 år. Denne udgift, som sandsynligvis er stærkt undervurderet, vil selvfølgelig påvirke tre andre tikkende bomber. Jeg vender tilbage til flyindustriens rolle i svensk forsvarspolitik, og til hvad Schweiz betyder i denne sammenhæng.

\section{Fortrængt krigsperspektiv}

Som det er fremgået, er det svenske forsvar både nu og fremover meget svagt med en lille personelstyrke og store mangler med hensyn til materiel og øvelser. Hvordan kan det være, at Sverige ikke får større forsvarseffekt for de godt 40 milliarder kroner, som går til forsvaret hvert år?

Det skyldes flere samvirkende forhold, hvoraf nogle er specifikke for Sverige:
Et første forhold er selvfølgelig, at bevillingerne til forsvaret er formindsket kraftigt; men det er ikke unikt for Sverige. I 1982 gik 2,9 procent af bruttonationalproduktet (BNP) til forsvaret, og i 2012 var andelen 1,1 procent. Det har naturligvis været en svær proces. Man ved, at det er svært at slanke en organisation. Hærenheder, orlogsskibe og flyvestationer er slagtet i et væk, mens den overordnede administration er slanket langt mindre. Overhead-omkostningerne tager en stadig større del af bevillingerne.

Et andet forhold, som delvis forklarer dette, er den svenske militærkulturelle - hvis man kan tillade sig dette udtryk - historiske arv. I lande med krigserfaring som $\mathrm{fx}$ Finland eller med medlemskab af NATO som fx Danmark er det naturligt, at man ikke helt tænker bort, hvad der kræves, hvis det værste skulle ske, altså krig.

I Sverige, som har haft fred i snart 200 år, er krigsperspektivet - what it takes to make war - i næsten freudiansk betydning fortrængt i den militære planlægning. Med en stadig dårligere økonomi har det helt afgørende perspektiv været: Hvordan erstatter man en meget stor krigsorganisation fra Den Kolde Krig med nyt og moderne materiel? Hæren valgte lavere kvalitet, men med fastholdt størrelse. Flyvevåbnet og søværnet valgte høj kvalitet; men antallet kampfly og orlogsskibe blev gradvis beskåret. Siden 1958 har hæren og 
flyvevåbnet uændret fået hver 30 procent af forsvarsbevillingerne og søværnet 15 procent. I dette stive system var planlægningsofficererne helt dominerende, og deres job var også vejen til generalstjernerne. For mange officerer var det karrierefremmende at få deres værns prioriterede projekter 'ind' i planerne, og det skete ofte ved hjælp af bevidst overoptimistiske kalkuler. De operative, dvs. de der skulle tænke på krig, førte en mere skjult tilværelse.

Efter afslutningen af Den Kolde

Krig udbrød, hvad man næsten kan kalde panik blandt svenske officerer. Man famlede desperat efter en opgave. I 1990'erne talte man om, at landet kunne tage en strategisk timeout og bruge pengene til at udvikle et højteknologisk forsvar med ITnetværk, sensorer, raketter, ubemandede fly og anden science fiction. Der blev satset mange milliarder, som i høj grad gik til konsulenthonorarer og PowerPoint-præsentationer. Fra år 2000 blev vægten især lagt på internationale opgaver, altså en vej svarende til den, Danmark havde valgt. Resultatet er 'en-ugesforsvaret', hvis det da nogensinde bliver til noget.

Georgienkrigen i 2008 blev dog et wake-up call. Krig i Europa forekom ikke længere utænkelig, og det gav skarpere fokus på det nationale forsvar. En vis opbygning af regionale kommandoer er påbegyndt som et første tegn på, at territorialforsvaret ikke er helt overset. Selv en vis ope- rativ planlægning finder sted. Men den militære struktur er fortsat først og fremmest tilpasset internationale opgaver.

Fra svensk side afgav man i 2009 den unilaterale solidaritetserklæring. Ifølge den skal Sverige ikke forholde sig passiv i tilfælde af, at kriser rammer EU-medlemmer eller nordiske lande, og det svenske forsvar skal kunne give dem militær støtte, hvis det er nødvendigt. Sverige forventer tilsvarende støtte, hvis det selv skulle bliver ramt.

Solidaritetserklæringen er i omverdenen blevet modtaget med bedøvende, nærmest forlegen tavshed, hvilket ikke er overraskende i betragtning af, at de ressourcer, Sverige ville kunne tilbyde, er så overordentligt små. Solidaritetserklæringen nævnes efterhånden sjældent og kun der, hvor en fortielse ville betyde, at man havde trukket denne nye doktrin tilbage. Regeringen fortsætter imidlertid med at argumentere, som om den regner med hjælp fra NATO-lande, hvis nogen del af Sverige skulle blive udsat for angreb. Repræsentanter for NATO bl.a. Anders Fogh Rasmussen - har dog slået fast, at der ikke ligger nogen automatik i dette.

\section{Forsvarsindustriens indflydelse}

Til syvende og sidst handler de skarpe beslutninger i svensk forsvarspolitik om materielanskaffelser. Det gjaldt under Den Kolde Krig, og det 
gælder i dag. Lidt drastisk udtrykt kan man ligne forsvaret ved hunden og forsvarsindustrien ved dens hale. Her er det bare halen, der logrer med hunden.

Erfaringen med at være afskåret fra våbenimport under Den Anden Verdenskrig førte til opbygning af en for et lille land omfattende våbenindustri. Den er en stærk og ofte afgørende magtfaktor. Den samarbejder med de militære planlæggere, som knytter deres karriere til dens produkter, og ganske ofte med stærke politiske interesser. Jeg har i den svenske offentlige debat talt om en 'jerntrekant', hvor der ofte hersker næsten incestuøse forhold. Det seneste eksempel er, at den konservative politiker Sten Tolgfors, som blev tvunget til at gå af efter en skandale i 2012, er blevet ansat som lobbyist i en PR-virksomhed med stærke bånd til forsvarsindustrien. Flere lignende tilfælde er forekommet tidligere.

Forsvarsindustriens indflydelse betyder, at man har prioriteret svenske våbensystemer frem for udenlandske, som måske er billigere og svarer bedre til behovet. Den svenske stat giver stærk støtte til forsvarsindustriens eksportbestræbelser, som er blevet vigtigere, fordi det svenske forsvar nu køber så korte serier. Men for at eksportere må den svenske forsvarsindustri kunne vise, at det svenske forsvar køber; for uden bestillinger hjemme er det svært at få eksportordrer. Der er brug for sven- ske bestillinger som reference.

Dertil kommer, at svensk forsvarsindustri ofte har meget høje ambitioner om at udvikle state-of-the-art systemer i teknisk front. Dette indebærer, at der tages betydelige tekniske og økonomiske risici. I nogle tilfælde har det resulteret i vellykkede systemer, i andre i tekniske/ økonomiske havarier. Et eksempel på det sidste er stealth-korvetterne af Visbyklassen, som tolv år efter den første søsætning stadig må betragtes som $a$ work in progress.

Jeg vil gå så langt som at hævde, at forsvarspolitikkens primære motiv ikke er strategisk eller operativt, ikke at få så høj forsvarseffekt som muligt for pengene, men at holde liv i forsvarsindustrien i Sverige.

\section{Nye systemer}

Der er dog udarbejdet en ny strategi for materielanskaffelser. Her siges det, at forsvaret principielt skal købe færdige systemer, selv udefra, eller lade svensk industri udvikle nye systemer i samarbejde med udenlandsk industri. Der findes virkelig nogle få eksempler på dette. Men strategien gælder ikke tunge systemer som fx fly og ubåde.

Det største problem med en svensk industri, som udvikler egne fly, er at den fremtvinger alt for hyppig indskiftning af nye flygenerationer. Kampfly med mange års teknisk og operativ levetid skrottes i utide. Det sker, fordi ingeniørerne på 
SAAB har brug for nye projekter. Det samme gælder de fabrikker, hvor flyene bygges. Problemet er blevet sværere med årene, fordi kampflyenes levetid i princippet $\emptyset$ ges for hver generation.

I Sverige er først Draken-, derefter Viggen- og sidst JAS A/B-flyene blevet skrottet $\mathrm{i}$ utide for at give plads til næste flytype. For hvert således fremtvunget generationsskifte falder antallet af fly drastisk. Det øger stykprisen. Nu planlægger man at tage teknisk og operativt fuldt brugbare JAS C/D-fly ud i 2020'erne, skønt de ville kunne holde 5-10 længere. Dette for at give plads til 'Super-JAS' $39 /$ E.

Det er bemærkelsesværdigt, at et lille land som Sverige med stadigt skrumpende forsvarsbevillinger tillader sig at holde liv i udviklingen af egne fly, eftersom de tætte generationsskift af flyene naturligvis er kostbare og går ud over det samlede forsvars operative formåen. I den forbindelse kan det være værd at notere, at Storbritannien og Frankrig efter alt at dømme ikke vil udvikle egne kampfly i fremtiden, og det vil måske end ikke ske i et europæisk flyindustrielt samarbejde. Desuden kan man konstatere, at praktisk taget alle vitale subsystemer til JAS importeres, først og fremmest fra USA. Men systemviden er selvfølgelig ikke uden betydning.

Naturligvis motiveres nye fly officielt altid med militære behov. Men det er i høj grad window dressing. Det egentlig, seriøse motiv er industripolitisk. Den kompetence, som er nødvendig for at udvikle og bygge fly, siges at have store spredningseffekter til den øvrige svenske industri. Det kan der være meget om; men problemet er, at omkostningerne er så høje, at det går ud over forsvarets operative formåen.

\section{Svenske eksportforhåbninger}

Ikke mindst fra politisk hold står håbet til eksport. Det er lykkedes $\mathrm{SAAB}$ at eksportere eller udleje fly til en håndfuld andre lande; men det har ikke kastet nogen stor gevinst af sig - køberen ved jo, at sælgeren har desperat behov for at sælge. En seriøs køber må selvfølgelig være overbevist om, at svensk flyindustri kan servicere flyene i hele deres 30-40-årige levetid. Her er der nok ofte tvivl hos potentielle købere. Men eksportdrømmene ser ud til aldrig at høre op. I anden forbindelse har jeg kaldt det en slags forsvarsindustripolitisk ludomani.

Hvor vigtige disse eksportforhåbninger er - ikke mindst på politisk hold - fremgår af den rolle Schweiz er kommet til at spille for beslutningen om at udvikle den såkaldt Super-JAS. Sveriges riksdag har sat som betingelse for en positiv beslutning, at udviklingsomkostningerne kan deles med et andet land, i praksis Schweiz. Selv forsvaret har den opfattelse. Der er forhandlinger med Schweiz om salg af 22 JAS 39 for lige 
så mange milliarder svenske koner. Regeringen har med vanlig optimisme regnet med, at handelen bliver til noget, og den bestilte i 2012 4060 nye fly.

Begivenheder i 2013 har imidlertid medført, at det synes højst usandsynligt, at Schweiz gennemfører købet. Der er dukket mange forhindringer op både i parlamentet og i form af en sandsynlig folkeafstemning. Det forekommer sandsynligt, at Schweiz trækker sig ud.

Betyder det, at Super-JAS ikke bliver til noget? Min vurdering er, at den svenske regering går videre med et rent svensk køb.

Ved for nylig at øge den svenske ordre fra 40-60 til 60 fly har man sikret sig, at det svenske flyvevåben 'absorberer' tabet, hvis handelen med Schweiz ikke bliver til noget. Forsvarsministeren er endog pludselig med vage formuleringer begyndt at tale om, at man har 'handlefrihed'. Dette vil tage yderligere midler fra andre dele af forsvaret, og 'en-ugesforsvaret' bliver dermed et fatamor- gana, som fortoner sig stadig hurtigere.

Der er dog også noget at glæde sig over. Svenske enheder har klaret sig godt i Bosnien, Kosovo, Congo, Adenbugten og Libyen. Det gælder også Afghanistan, hvor man dog har opereret i et betydeligt fredeligere område end det Helmand, hvor danskerne har været.

I to omgange har Sverige haft ansvar for Nordic Battle Groups i en EU-ramme. Det har været en øjenåbner for mange svenske officerer, som har skullet sætte sig ind i, hvad der kræves af en bataljonsgruppe, som kan blives at ind i kamp. Men denne erfaring bliver der efter alt at dømme ikke penge til at omsætte i andet end nogle få militære enheder.

Johan Tunberger er tidligere overingeniør ved Totalförsvarets Forskningsinstitut og medlem af Kungliga Krigsvetenskapsakademien.

(Oversat fra svensk af Klaus Carsten Pedersen). 